
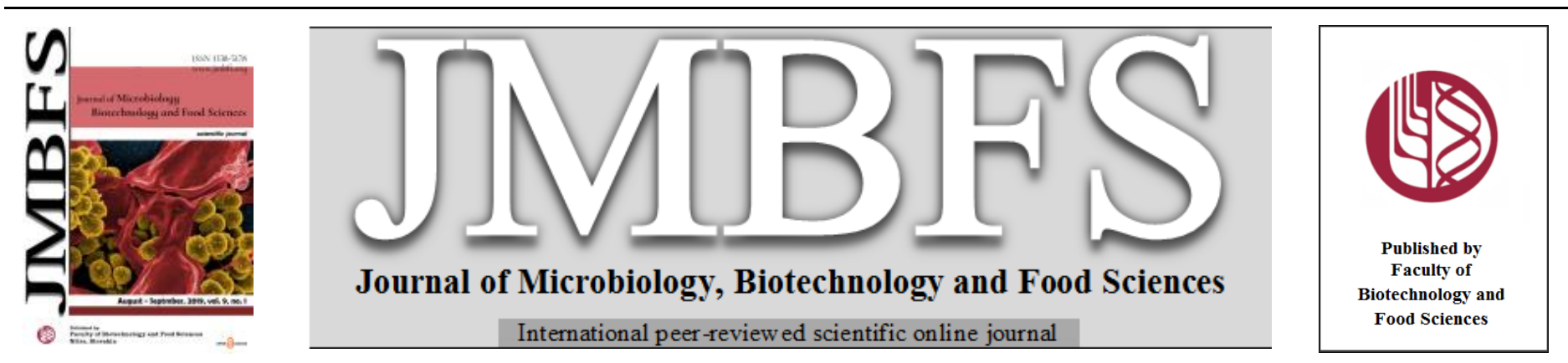

\title{
ISOLATION AND CHARACTERIZATION OF A NOVEL AGAR-DEGRADING BACTERIUM, Microbacterium barkeri sp. SELA 4, FROM SOIL ENRICHED WITH LABORATORY AGAR
}

\author{
Shomini Parashar, Narendra Kumar* \\ Address(es): Narendra Kumar, \\ IMS Engineering College, Department of Biotechnology, NH-24 Adhyatmik Nagar, Ghaziabad, India- 201015.
}

*Corresponding author: narendra.kumar@imsec.ac.in

doi: 10.15414/jmbfs.2019.9.1.78-83

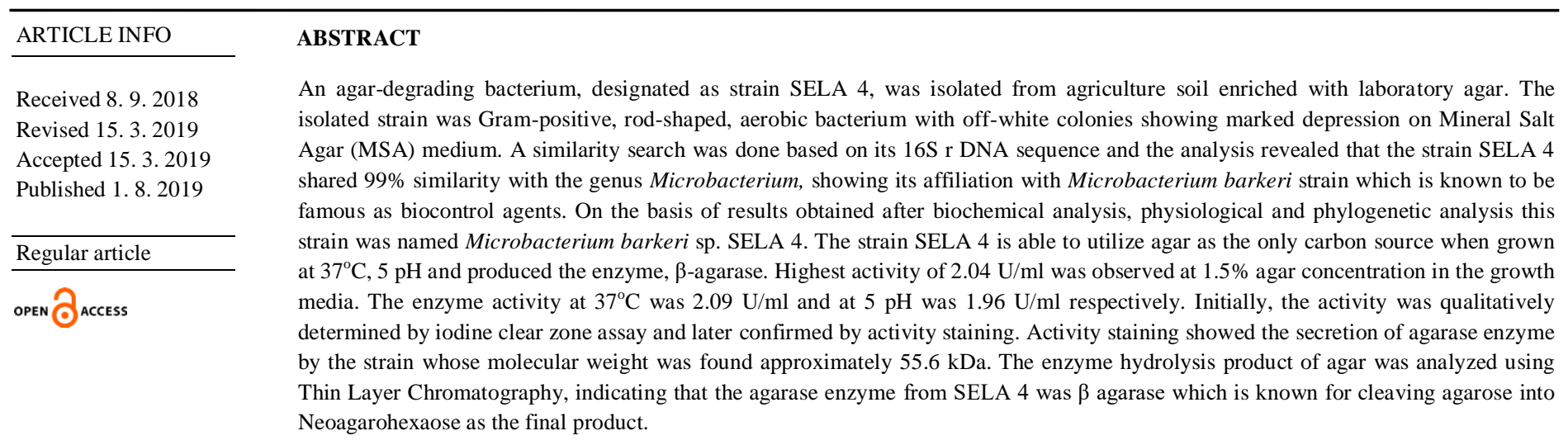

Keywords: Activity staining, Biocontrol, Microbacterium, MSA, Neoagarohexaose, Agarase, Hydrolysis

\section{INTRODUCTION}

The great utility of the agar hydrolyzed oligosaccharides has attracted some researchers in this area. The bacterial isolate, Microbacterium sp. SELA 4 mentioned in the current study, produced agarase enzyme which was isolated from soil enriched with laboratory agar and possess the ability to degrade agarose. Some red algae like Gelidium and Gracilaria are most popularly known for the location of two major components of agar, namely Agarose and Agaropectin in their cell walls. Both the components are polysaccharides in nature. The former component is a neutral molecule with linear chains of repeatedly alternating units of $\beta-1,3$ - linked-D-galactose and $\alpha-1,4$ linked 3,6 anhydro L-galactose (Duckworth and Turvey, 1969)has gelling abilities while the later component, is a non-gelling fraction of sulfated polysaccharide. Agarase enzymes act on the substrate, agarose of agar and break its polysaccharide into oligosaccharides. The agarases are of two types: $\alpha$-agarases (EC 3.2.1.158) and $\beta$ agarases (EC 3.2.1.81) on the basis of their cleavage pattern (Chi et al., 2012). The $\alpha$-agarase break $\alpha-1,3$ linkages to produce agaro-oligosaccharides while $\beta$-agarase enzyme breaks $\beta-1,4$ linkages to produce neoagarooligosaccharides (Suzuki et al., 2002). Agarase enzyme is used in biochemistry lab, to retrieve DNA from agarose gel (Sugano et al. 1993) while it's hydrolytic products are utilized in food industry as food additives and gelling agent (Fu and Kim, 2010), as anti-oxidants by scavenging the reactive free radicals (Wang et al., 2004), in cosmetics, as moisturizers for skin fairness(Kobayashi et al., 1997), in medicine industry, as immunity booster by exhibiting macrophage stimulating activity (Yoshizawa $\boldsymbol{e t}$ al., 1995). Agar-degrading bacteria are known to utilize agar for carbon requirement, unlike other bacteria for which agar just acts as a solidifying agent. Such bacteria were usually isolated from marine sources as the substrate, agar is available to them in the cell wall of red algae. However, few bacterial isolates have known to be reported from non - marine environments like Asticcacaulis sp.SA7 from rhizosphere soil (Hosoda et al., 2006), Paenibacillus sp.SSG-1 from soil (Song et al., 2014), Ammonibacillus agrariperforans FAB2(T) from sewage sludge compost (Sakai et al., 2015) and the endophytic bacteria isolated from the plant source (Song et al., 2015). Therefore, our study focuses to know the significance and ecology of non-marine agar-degrading bacteria.
Till now, no reports are there on agarolytic bacterial isolates, that belong to Microbacterium species either from marine or non-marine sources. Our current study describes the identification of a novel agar degrading bacterial strain, SELA 4, molecular weight determination of its agarase enzyme, detection of enzyme hydrolysis products and the effect of different parameters (agar conc., temperature, $\mathrm{pH}$ ) on the production of extracellular agarases. There are reports about a few strains of Microbacterium sp. that cause diseases in plants (Kaku $\boldsymbol{e t}$ al., 2000) animals (Hodgkin et al.,2000) and human beings (Alonso-Echanove et al., 2001) but recently few isolates from soil have also shown to possess biocontrol activity (Sartori et al., 2012) production of bio-ethanol(Kawaroe $\boldsymbol{e t}$ al., 2018). Through this article, we are for the first time mentioning about a novel agar-degrading bacterium, Microbacterium barkeri sp., SELA 4 which extracellularly secretes $\beta$ agarase enzyme with molecular weight 55.6kDa and has the potential to produce Neoagarohexaose.

\section{MATERIAL AND METHODS}

\section{Isolation of agar degrading bacterium and its culture medium}

An agarolytic bacterium was isolated from the agriculture soil sample on Mineral Salt Agar plates. The compositions for MSA agar medium were (gram per liter): $\mathrm{CaCl}_{2} 0.1 ; \mathrm{MgSO}_{4} .7 \mathrm{H}_{2} \mathrm{O} 0.5 ;\left(\mathrm{NH}_{4}\right)_{2} \mathrm{SO}_{4} 0.5 ; \mathrm{K}_{2} \mathrm{HPO}_{4} 0.5 ; \mathrm{NaCl} 0.5 ; 1.5 \%$ agar. To inhibit the growth of fungi on the plates, $5 \mathrm{~g} / \mathrm{l}$ of Nystatin was added to culture media whose $\mathrm{pH}$ was adjusted to five. One gram soil was taken from the pot containing agriculture soil in which laboratory agar wastes were regularly dumped and mixed. Then this one gram soil thoroughly mixed with $100 \mathrm{ml}$ distilled water and through serial dilution method; $0.1 \mathrm{ml}$ of the suspension was taken from each dilution tubes $10^{-4}, 10^{-5}, 10^{-6}$, spread on Petriplates containing MSA. The Petri plates were then incubated at $37^{\circ} \mathrm{C}$ temperature for several days and were daily checked for agarolytic activity. After three days of incubation, colonies forming depression and zones around them on the smooth agar surface were selected and sub-cultured on fresh MSA plates for further purification. Total 4 different bacterial colonies appeared on the smooth agar plates. Out of these only one which showed marked depression and zone of clearance, was picked and examined for colony characteristics. 


\section{Morphological, physiological and biochemical characteristics}

After getting the pure culture of the agarolytic bacterium after 3 days of incubation at $37^{\circ} \mathrm{C}$, the culture was observed for its colony morphology like margins, elevation, pigmentation, opacity, the texture on solid and smooth agar plates. The Morphology of the bacterium was examined with a light microscope. Physiology analysis and biochemical tests were conducted as described by $\mathbf{L i}$ and Gao (1997).

\section{Qualitative and Quantitative assay for agarase activity}

For the qualitative assay, one culture plate was taken and poured on with Lugol's iodine solution. The iodine solution stains the agar polysaccharide dark brown while the degraded polysaccharide portion of the agar plate shows a zone of light color. For the quantitative estimation of enzyme activity, DNSA method (Miller, 1959) was used. In this test the agarase activity was measured as the enzyme releases the reducing sugar equivalent using DNSA (3,5-di-nitrosalicylic acid) and the increasing concentration of reducing sugar was determined with the help of spectrophotometer at $540 \mathrm{~nm}$ wavelength, keeping D-galactose as standard.

\section{Partial purification of Agarase enzyme}

MSA broth supplemented with $0.3 \%$ (w/v) agar was prepared and the isolated culture was inoculated into it. The flasks having $50 \mathrm{ml}$ of culture media was inoculated with $1 \mathrm{ml}$ of culture in its $\log$ phase. The flasks were incubated at $37^{\circ} \mathrm{C}$ for 24 hours on a rotary shaker at $170 \mathrm{rev}$ min-1. After 24 hours of incubation, the cultures were centrifuged at $10,000 \mathrm{rev}$ min- 1 for $10 \mathrm{~min}$. at $4^{\circ} \mathrm{C}$. The pellet was discarded and the supernatant was used for assaying the enzyme activity.

\section{Agarase activity detection}

For calculating the enzyme activity, the galactose stock solution was prepared by mixing $250 \mathrm{mg}$ of galactose in $100 \mathrm{ml}$ of distilled water. From this stock solution, $1 \mathrm{ml}$ solution was taken and mixed with $9 \mathrm{ml}$ of distilled water so that the working solution could be prepared. In 7 dry and clean test tubes, standard sugar solution was pipette out in the range of 0 to $3 \mathrm{ml}$ and the final volume of each test tube was adjusted to $3 \mathrm{~mL}$ with distilled water. Finally, every tube was added with $1 \mathrm{ml}$ DNSA reagent and by putting the cotton plug, the tubes were kept in boiling water bath for 5 minutes. After allowing the tubes to cool at room temperature, OD was taken at $540 \mathrm{~nm}$ against the blank. The reducing sugars data were expressed as galactose equivalents. For measuring the enzyme activity, 100 $\mu 1$ sample of enzyme supernatant (described above) was added to $900 \mu 1$ Phosphate Buffer Saline (pH, 7.0) with $0.25 \%$ agar substrate and incubated for 15 minutes at $37^{\circ} \mathrm{C}$. Initial OD was recorded. Then $1 \mathrm{ml}$ of this reaction mixture was added with $2 \mathrm{ml}$ of DNSA reagent and heated for approximately 5 minutes at $100^{\circ} \mathrm{C}$ in the water bath. After allowing the mixture to cool, it is diluted with 10 $\mathrm{ml}$ of distilled water and optical density reading was taken at the abovementioned wavelength. The enzyme activity was measured in Units per ml. One unit is that quantity of the enzyme which released $1 \mu$ mol reducing sugar (galactose) per minute from agar substrate under defined conditions (Suzuki et al., 2002).

Effect of agar concentration, Temperature, and pH on the activity of agarase enzyme

For calculating the agarase activity at various conditions, $0.2 \mathrm{ml}$ of exponential growth phase culture was inoculated into a clean Erlenmeyer flask of $100 \mathrm{ml}$, containing $20 \mathrm{ml}$ MS broth with varying concentration of agar. The different agar concentrations taken were $0.05 \%, 0.1 \%, 1.5 \%$ and $2.0 \%$ agar. Cultures were incubated in an incubator shaker at 170 revs. The growth of bacterium at different agar concentration, temperature and $\mathrm{pH}$ was measured by the spectrophotometer and the enzyme activity was recorded. For agarase activity assay, the bacterial cells and the residual gel in the flask were removed after centrifugation at 10,000 rev $\min ^{-1}$ for $10 \mathrm{~min}$. at $4{ }^{\circ} \mathrm{C}$. The supernatant so obtained, was consumed for quantifying the agarase enzyme activity. The activity was plotted graphically to determine the optimal growth at varying agar concentration, temperature, and $\mathrm{pH}$. The temperature variations taken were $30^{\circ} \mathrm{C}, 35^{\circ} \mathrm{C}, 37^{\circ} \mathrm{C}, 40^{\circ} \mathrm{C}$, and $45^{\circ} \mathrm{C}$ Agarase activity was taken at these different temperatures and plotted against it. The $\mathrm{pH}$ variations taken were 5, 7, 9 and 11. The buffer solution of these different $\mathrm{pH}$ was prepared. $0.1 \mathrm{ml}$ of the partially purified agarase enzyme was added to $0.9 \mathrm{ml}$ of a buffer solution containing $0.5 \%$ agar for enzyme activity to be assayed for each different $\mathrm{pH}$.

\section{Identification of the bacterium by $16 \mathrm{~S}$ rDNA sequencing}

The identification of bacterial isolate, SELA 4was performed by $16 \mathrm{~S}$ rDNA sequencing. The extracted DNA was used as a template for PCR amplification of the $16 \mathrm{~S}$ rRNA gene sequence of length 1466bp. Universal primers complementary to the conserved regions were used so that the region could be amplified using 27F - 5' AGAGTTTGATCMTGGCTCAG 3' and 1492R - 5 TACGGYTACCTTGTTACGACTT 3'. PCR was performed. For initial denaturation, in the $1^{\text {st }}$ cycle, the temperature kept was $94^{\circ} \mathrm{C}$ for 2 minutes. The PCR machine was set for 25 cycles of annealing and extension of DNA $\left(98^{\circ} \mathrm{C}\right.$ for $10 \mathrm{sec} ; 53^{\circ} \mathrm{C}$ for $30 \mathrm{sec} ; 68^{\circ} \mathrm{C}$ for $1 \mathrm{~min}$ ). The Standard protocols were used for PCR products purification, which was further directly sequenced using Big Dye Terminator v3.1 Cycle Sequencing Kit (Applied Biosystems). A 16S rDNA sequence of length 1466bp obtained from SELA 4was submitted to GenBank Phylogenetic tree construction and analysis were done using MEGA 6.0 software.

\section{Partial purification of agarase from the culture broth}

The extracellular agarase enzyme was extracted from the flask after 24 hours of growth in the culture medium. The culture was cooled at $4^{\circ} \mathrm{C}$ for $30 \mathrm{~min}$. After which, the cells were separated by centrifugation at $10,000 \mathrm{rev} / \mathrm{min}$ for 10 minutes at $4^{\circ} \mathrm{C}$ temperature. Solid ammonium sulfate at $80 \%$ saturation was calmly added to the supernatant containing the enzyme by constant stirring for an hour. The precipitate obtained was further purified by the process of centrifugation at $12,000 \mathrm{rpm}$ for $30 \mathrm{~min}$ at $4{ }^{\circ} \mathrm{C}$. The supernatant was carefully separated from the tube leaving behind the pallet. The pallet having the enzyme was then dissolved in Tris $\mathrm{HCl}$ buffer and dialyzed according to Lakshmikanth et al., (2006).

\section{SDS -PAGE and activity staining}

The agarase enzyme which was partially purified by the above process was separated using an SDS-PAGE system. 12\% SDS Polyacrylamide gel was prepared and performed similarly to Laemmli (1970). From the partially purified agarase enzyme, $10 \mu 1$ sample was mixed with equal volumes of SDS loading buffer and incubated at $40^{\circ} \mathrm{C}$ for 40 minutes to reduce and denature the protein for effective separation. In another well, protein molecular weight markers were also allowed to run with the sample. The process of electrophoresis was carried out at $30 \mathrm{~mA}$ for 3.5 hours at room temperature. After electrophoresis, several protein bands obtained were stained with Coomassie brilliant blue R 250 for overnight and then de-stained to visualized proper blue agarase bands over visible light. The activity staining was done according to Lakshmikanth $\boldsymbol{e t}$ al.(2006) with some modifications. After SDS PAGE, the gel was soaked in $20 \mathrm{mM}$ Tris- $\mathrm{HCl}$ buffer $\mathrm{pH} 7$ for 30 minutes to remove SDS. To hasten the process, the soaking buffer changed thrice. The gel was then overlaid onto the plate containing $1.0 \%(\mathrm{w} / \mathrm{v})$ agarose gel in $20 \mathrm{mM}$ Tris- $\mathrm{HCl}$ buffer with $\mathrm{pH} 7$ and incubated for 30 minutes at $40^{\circ} \mathrm{C}$. The gel was separated from the gel plate and then flooded with Gram's iodine to visualize the agarase activity.

\section{Identification of enzyme-hydrolyzed products}

Thin layer chromatography (TLC) was performed for identifying these enzyme hydrolysis products of agarose (Kim et al., 1999). LMP-agarose was enzymatically hydrolyzed in $200 \mathrm{ml}$ of $20 \mathrm{mM}$ Tris- $\mathrm{HCl}$ buffer $\mathrm{pH} 7.0$. The reaction mixture was incubated for about 2 hours at $40^{\circ} \mathrm{C}$. After 2 hours, the reaction of the enzyme was stopped after heating the samples in a boiling water bath for a minute. The lysate mixture was later analyzed for hydrolysis products. The lysates were applied to activated silica gel-G-coated TLC glass plates. The Petri plates were chromatographed with n-butanol: acetic acid: water $(2: 1: 1, \mathrm{v} / \mathrm{v})$ as a solvent system. The resolved compounds were visualized by spraying with Naphthoresorcinol reagent followed by heating at $100^{\circ} \mathrm{C}$ in a hot air oven for 10 min.

\section{RESULTS}

\section{Isolation of agar degrading bacterium and its culture medium}

A novel bacterial strain that degrades agar degrading, was isolated from the agriculture soil enriched with laboratory agar. The strain produced depression on the plates and showed a remarkable zone of clearance around them. The bacterial strain SELA 4 was grown at $37^{\circ} \mathrm{C}, \mathrm{pH} 5$ and sub-cultured regularly on MSA media slants containing agar only for carbon and energy source. Fig1 shows the recently isolated strain SELA 4 that showed depression on the smooth agar surface.

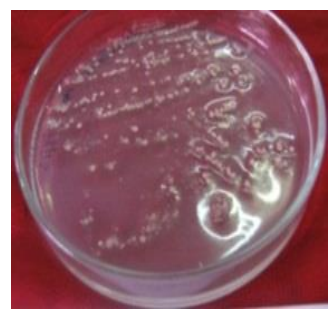

Figure 1 Culture plate ofthe SELA4 strain isolated from Agriculture soil enriched with laboratory agar 


\section{Qualitative assay for agarase activity}

After selecting the colonies that degraded agar, the streaked plate was taken and poured on with Lugol's iodine solution. After a few seconds, the entire culture plate having the culture showed a light-colored translucent zone as shown in Fig 2
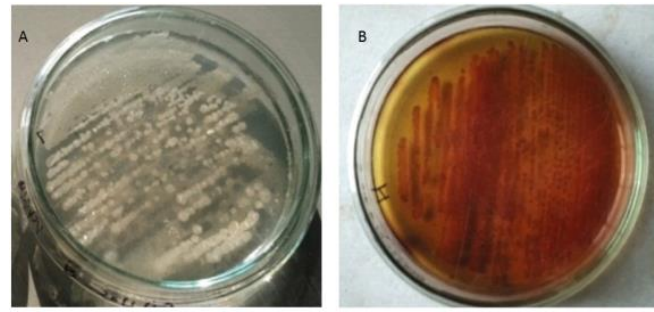

Figure 2 SELA 4 Plate showing translucent zone (B)

A: Before adding Iodine solution; B: After adding Iodine solution

\section{Morphological, physiological and biochemical characteristics}

The morphological, physiological and biochemical features of the strain SELA 4 were investigated and compiled in Table 1. The cells of the strain SELA 4 cultured for 3 days at $37^{\circ} \mathrm{C}$ were gram-positive, rod-shaped, capsular negative, aerobic, non-motile and formed smooth, off-white, flat colonies with entire margin on Mineral Salt Agar media plates. The biochemical analysis revealed that the strain SELA 4, hydrolyzed gelatin and utilized Arabinose, Glucose, Inositol, and Sucrose.

Table 1 Biochemical and physiological characteristics of strain SELA 4

\begin{tabular}{ll}
\hline Characteristic & Result \\
\hline Cell shape & Rod \\
Margin & Entire \\
Elevation & Flat \\
Texture/Surface & Smooth \\
Colour & Off-white \\
Gram stain & + \\
Capsule & - \\
Cilium & - \\
Polar flagellum & - \\
Catalase & - \\
\hline
\end{tabular}

\begin{tabular}{ll}
\hline Oxidase & - \\
Growth at & ++ \\
$30^{\circ} \mathrm{C}$ & ++++ \\
$35^{\circ} \mathrm{C}$ & +++++ \\
$37^{\circ} \mathrm{C}$ & ++++ \\
$40^{\circ} \mathrm{C}$ & +++ \\
$45^{\circ} \mathrm{C}$ & - \\
Urea hydrolysis & + \\
Gelatin hydrolysis & - \\
Acetoin production(Voges-Proskauer test) & - \\
Indole production & - \\
Citrate utilization & + \\
Arabinose utilization & + \\
Glucose utilization & + \\
Inositol utilization & + \\
Sucrose utilization & + \\
Fructose utilization & - \\
\hline + positive/utilizable, -negative/non-utilizable,,,,++++++++++++++ increasing amount of \\
growth
\end{tabular}

Effect of different agar concentration, temperature, and $\mathrm{pH}$ on the agarase activity

Fig 3(A) showed the effect of various agar concentrations on the activity of partially purified agarase from Microbacterium sp. SELA 4. The results showed that the agarolytic activity of $2.04 \mathrm{U} / \mathrm{ml}$ was observed as highest when the agar concentration in the media was $1.5 \%$ while it slightly decreased to $1.9 \mathrm{U} / \mathrm{ml}$ when the agar concentration was increased to $2 \%$. This shows that increasing the level of the substrate has no effect on the activity above a limit of $1.5 \%$. The reason may be saturation of active sites with the substrate. The results of Fig 3(B) indicated that the activity of agarase enzyme reached the maximum, $2.09 \mathrm{U} / \mathrm{ml}$ at $37^{\circ} \mathrm{C}$ and decreased to $1.57 \mathrm{U} / \mathrm{ml}$ and $1.26 \mathrm{U} / \mathrm{ml}$ with increasing temperature $40^{\circ} \mathrm{C}$ and $45^{\circ} \mathrm{C}$ respectively. This may be due to the denaturation of enzymes caused by structural deformity after incubation at high temperatures. For investigating the optimum $\mathrm{pH}$ for agarase activity, enzymes were incubated at $37^{\circ} \mathrm{C}$ in buffer solutions with pH 5,7,9,11. Results in Fig 3(C) indicated that the enzyme showed the maximum activity of $1.96 \mathrm{U} / \mathrm{ml}$ at $\mathrm{pH} 5$ which decreased to $1.42 \mathrm{U} / \mathrm{ml}, 1.14 \mathrm{U} / \mathrm{ml}$ and $0.96 \mathrm{U} / \mathrm{ml}$ at $\mathrm{pH} 7,9$ and 11 respectively. Increasing $\mathrm{pH}$ might have caused enzyme inactivation due to the formation of an ionic form of enzyme active sites.
(A)

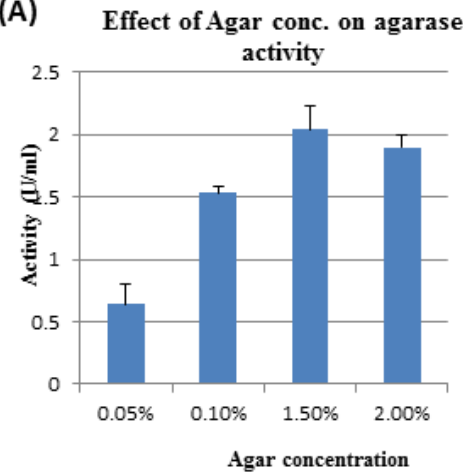

(B) Effect of Temperature on agarase activity

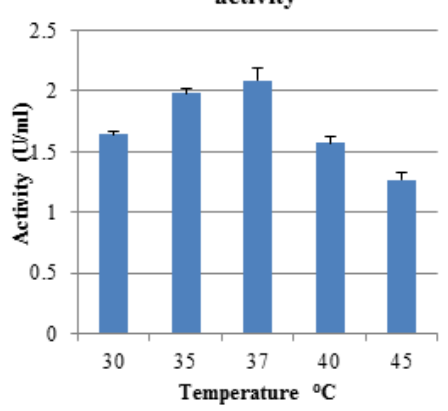

(C) Effect of $\mathrm{pH}$ on agarase activity

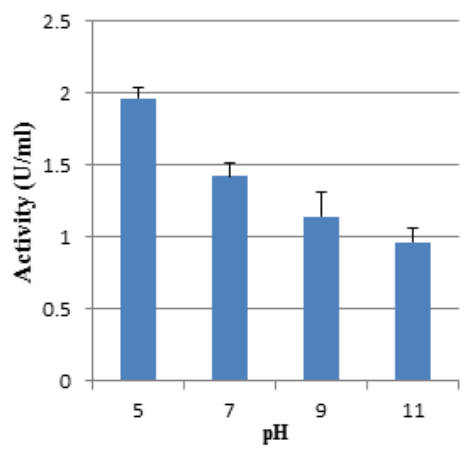

Figure 3 The above figure presents the bar graph showing (A) the effect of different Agar concentrations, $0.05 \%, 0.10 \%, 1.50 \%$ and $2.0 \%$ (B)Effect of temperature, $30^{\circ} \mathrm{C}, 35^{\circ} \mathrm{C}, 37^{\circ} \mathrm{C}, 40^{\circ} \mathrm{C}$ and $45^{\circ} \mathrm{C}(\mathrm{B})$ effect of $\mathrm{pH} 5,7,9$ and 11 , on agarase activity of SELA 4 . The error bar shows the standard deviation.

\section{Phylogenetic affiliation of the strain SELA4 through 16S rDNA sequence}

The sequence of the PCR product of length 1466bp from 16S rDNA of SELA 4 was used as a query sequence for an initial similarity search against the sequences of NCBI's Gen Bank database. BLASTn tool was used for homology search and the search results of the 16S rDNA for the strain SELA 4 showed its close relationship to Microbacterium barkeri strains with $99 \%$ sequence similarity. A Phylogenetic tree of the Strain SELA 4 was constructed(Fig 4) using $16 \mathrm{~S}$ rDNA sequences. The query sequence matched $99 \%$ in similarity with Microbacterium sp. through the results obtained by BLASTn. Multiple Sequence Alignment and the construction of the phylogenetic tree was done by Maximum Likelihood statistical method using MEGA 6: Molecular Evolution Genetics Analysis Version 6.0. A bootstrap confidence analysis was cried out with 1000 replicates. Heuristic search tree was obtained when we take the parameters as Neighbor-Joining and BioNJ algorithms for a matrix of pairwise distances estimated using a JTT model. The topology was selected having superior log- likelihood value. 10 sequences were taken for analysis. The positions of sequence alignment having gaps and missing data were ignored. The results of the Phylogenetic analyses suggest that the strain SELA 4 is closely affiliated to Microbacterium barkeri strain DSM 20145, Accession No. NR 026164.1 (99\%), Microbacterium barkeri M3, Accession No. KY928100.1 (99\%) as they share a common ancestor. This cluster was found related to the other cluster of closely related sequences of Microbacterium genus, Microbacterium oryzae, and Microbacterium gilvum. Thus it was concluded that SELA 4 is a member of genus Microbacterium, species barkeri belonged to the class Actinobacteria. Among the existing agar degrading bacteria, none has been reported to belong to the genus Microbacterium. The 16S rDNA sequence of Microbacteriumbarkeri sp. strain SELA 4 has been deposited in GenBank database of NCBI under the accession no. MG203882.1 


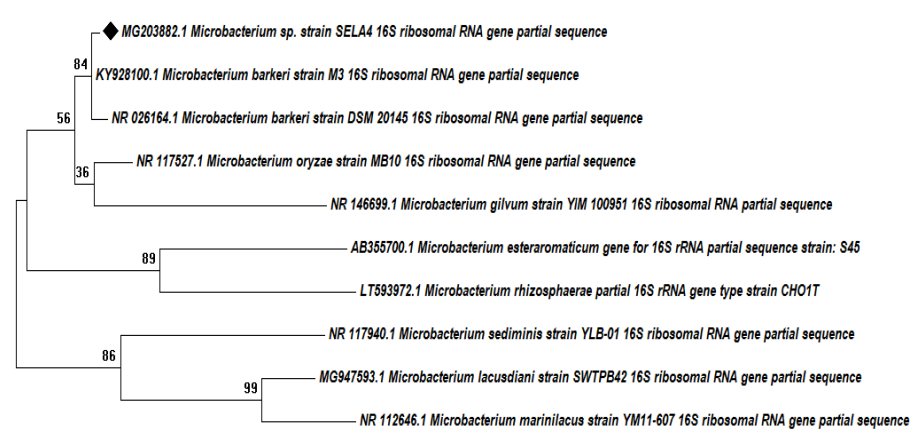

0.055

Figure 4 Phylogenetic tree of strain SELA 4, constructed from 16S rDNA nucleotide sequence using the Maximum Likelihood Method of statistica analysis. The tree shows the position of strain SELA 4 and the other species of the genus Microbacterium. The \% of replica trees in which the associated clustered taxa in the bootstrap test (1000 replica) are shown above the branches. Accession number of the 16S rRNA gene partial sequences are given in front of the species name. The scale bar of 0.005 shows substitution per nucleotide position.

\section{SDS -PAGE and activity staining}

For detecting the molecular weight of the enzyme produced by the bacterium, SDS-PAGE was run and the activity of the enzyme was detected by Activity staining (Fig 5). After Electrophoresis, four distinct bands were observed in the SDS gel in Lane 2 while Lane 1 showed the bands of Protein Molecular weight marker(G-Biosciences PAGEmark Blue Plus Protein marker) that ranged in size from 27 to $158 \mathrm{kDa}$. The positions of these markers are indicated on the left side of the gel. Out of the four bands in Lane 2, Band 2 showed a clear zone which corresponds to the enzymatic activity with Lugol's iodine solution. Thus a single band showing agarase activity was detected and the molecular weight was estimated to be about $55.6 \mathrm{kDa}$, corresponding to the molecular marker in Lane 1 .

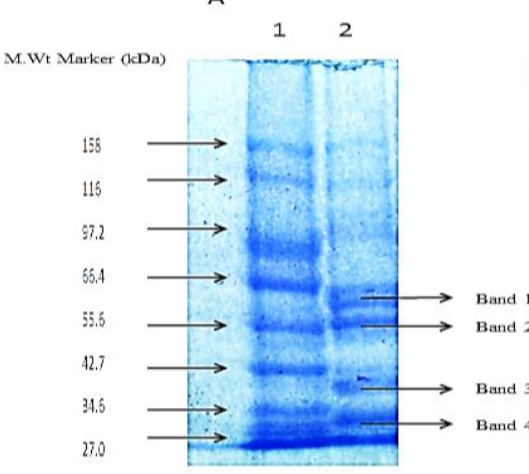

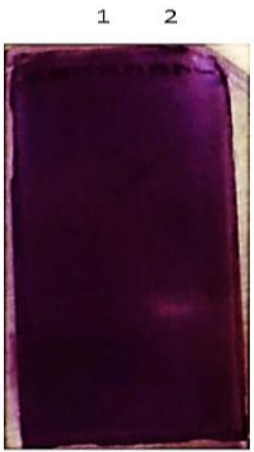

Figure 5 (A) SDA-PAGE profile and (B) Activity staining.

(A) Lane 1-Molecular marker; Lane 2-Enzymes from SELA 4.

(B) Band 2 in Lane 2 indicates putative agarase with the molecular wt. approximately $55.6 \mathrm{kDa}$

\section{Identification of enzyme-hydrolyzed products}

Neoagarohexaose was the oligosaccharide detected in the agarose hydrolysate after 120 min of incubation. (Fig 6) The results suggest that the agarase purified from the strain, SELA 4 belongs to $\beta$ agarase which specifically cleaves $\beta-1,4$ linkages found in agarose. The agaro oligosaccharides were also allowed to run along with agarose hydrolyzed products by the agarase on TLC but none of the product produced by the purified agarase matched the Rf values of the acid hydrolysis product of agarose (data not shown here). However, the Rf values correlated with the standard Neoagarohexaose after $120 \mathrm{~min}$. of incubation. Thus, it becomes clear that the agarase secreted by the bacterium, Microbacterium barkeri sp. SELA 4 is a $\beta$ agarase.

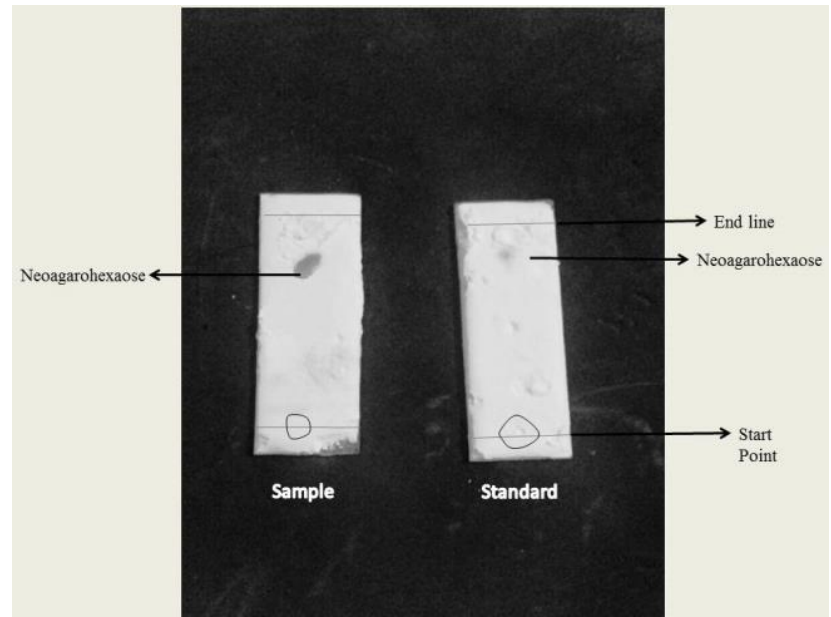

Figure 6 TLC of agarose hydrolyzed products.

(A) Agarose hydrolyzed product after $120 \mathrm{~min}$

(B) Standard- Neoagarohexaose

\section{DISCUSSION}

Strain SELA 4, isolated from agar enriched agriculture soil has the agarolytic activity which showed marked depression on an agar plate. It is rod-shaped, Gram-positive bacterium utilizing agar for carbon along with other mineral compounds. The biochemical characteristics exhibited by the isolate indicates it to be a member of class Actinobacteria. This class is well known for its potential to degrade a variety of stable organic compounds (Lewin et al.,2016)including natural and synthetic substances (Solvanikova and Golovleva, 2015). The strain required $1.5 \%$ of agar in the media for optimum enzyme activity of $2.04 \mathrm{U} / \mathrm{ml}$. Temperature and $\mathrm{pH}$ are considered important parameters regarding enzyme activity. It was noticed that the activity of SELA 4 consistently increased from $30-37^{\circ} \mathrm{C}$, with optimal activity of $2.09 \mathrm{U} / \mathrm{ml}$, at $37^{\circ} \mathrm{C}$. With increasing temperature, there was a decrease in the activity of the enzyme. When compared to the other agar degrading bacteria, SELA 4 has slightly lower optimum temperature requirement than many agarases (Kirimura et al., 1999; Suzuki et al., 2003; Temuujin et al., 2012; Lakshmikanth et al., 2006). The enzyme showed maximum agarase activity, $1.96 \mathrm{U} / \mathrm{ml}$ at $\mathrm{pH} 5.0$ which is similar to many other agarases (Oh et al., 2010;Ghazi et al.,2013;Temuujinet al., 2012). While agarases active at high $\mathrm{pH}$ have also been reported (Sakai $\boldsymbol{e t}$ al., 2015;Kim et al.,2012). $16 \mathrm{~S}$ rDNA gene sequencing confirms that the isolate belongs to the genus Microbacterium of class Actinobacteria, by showing $99 \%$ sequence similarity with Microbacterium barkeri strain DSM 20145(GenBank: NR 026164.1) and Microbacterium barkeri M3 (GenBank: KY928100.1).

Currently, most of the reported bacterial isolates producing agarase enzymes, are from marine sources (Fu and Kim, 2010). By far none of the research reports talks about the isolation of agarase enzyme producing bacteria belonging to genus Microbacterium. A relatively closer study is about the agarolytic isolates from the surface of macroalgae, affiliating to eleven different genera including Microbacterium (Alvarado et al.,2017). Recently this class has been exposed to possess good cellulose degrading activity (Rajagopal and Kannan, 2016). A few studies have been reported about the degradation of polysaccharide, xanthan by Microbacterium sp. Strain XT 11 (Qian et al., 2007) and the degradation of xylan by Microbacterium xylanilyticum sp.(Kim et al., 2005). The utilization of Arabinose, Glucose, Inositol and Sucrose, hydrolysis of gelatin and other physiological characteristics further ascertain the affiliation of SELA4 to Microbacterium sp.

In the current study, we isolated the agarase enzyme from Microbacterium barkeri sp. SELA 4, having a molecular weight of about $55.6 \mathrm{kDa}$ which is closer to $\beta$ agarases with molecular weight $52 \mathrm{kDa}$ (Leon et al., 1992) produced by gram-negative Alteromonas sp. C-1, Rhodococcus sp. Q5, 54kDa (Feng and Li, 2013), Bacillus sp.BI 3, 58kDa (Li et al., 2014) isolated from soil. According to Leon et al., 1992 the agarase enzymes present in agarolytic bacteria are of two types; Group I and Group II. Softening of agar and formation of depressions at the colonies is the characteristic feature of Group I while that of Group II is extensive liquefication. Vera et al. (1998)divided $\beta$-Agarases into 3 groups based on the size of the agarase enzyme. The molecular weight of group 1 is approximately $30 \mathrm{kDa}$, group 2 , approximately $50 \mathrm{kDa}$ and group 3 approximately $100 \mathrm{kDa}$. Hence, the isolated enzyme belongs to group $2 \beta$ agarases. The isolate Microbacterium barkeri sp. SELA 4 was grown at $37^{\circ} \mathrm{C}$ with $\mathrm{pH} 5$ which is similar to other agarolytic bacterial isolates like Streptomyces coelicolor A3(2) (Temuujin et al., 2012) and Acinetobacter sp. AGLSL-1 (Lakshmikanth et al., 2009) from the soil environment. The degradation of agar requires the sequential breakdown of agarolytic products by enzymes like $\beta$ agarase, which breaks down $\beta-1,4$ glycosidic bonds resulting in the production of neoagaro oligosaccharides (NAOs). Its major products are Neoagarobiose and Neoagarotetraose (Fu et al., 2009), Neoagarohexaose (Ohta et al., 
2004). Neoagarobiose is further converted to the products 3,6 anhydro Lgalactose and D-galactose which has skin fairness and anti-inflammatory effect on human (Kim et al., 2017). The agarolytic enzyme, $\alpha$ agarase cleaves $\alpha-1,3$ linkages to produce agaro-oligosaccharides (AOs). The present study showed that Microbacterium barkeri sp. SELA 4 hydrolyzed agarose to Neoagarohexaose. The same type of product was also produced by non-marine bacteria Paenibacillus sp. SSG-1(Song et al., 2014)Bacillus sp. BI-3 (Li et al., 2014)Streptomyces coelicolor A3(2)(Temuujin et al., 2012).

\section{CONCLUSION}

Based on our present study, it is summarized that Microbacterium barkeri sp. SELA 4 is the first report on an agarolytic bacterium that produce the enzyme $\beta$ agarase, isolated from soil enriched with laboratory agar. The enzyme showed the highest activity of $2.04 \mathrm{U} / \mathrm{ml} 1.5 \%$ agar in the culture media. The optimal temperature was $37^{\circ} \mathrm{C}$ as maximum activity was seen at this temperature while optimum $\mathrm{pH}$ was found to be 5 . It produces Neoagarohexaose, could prove to be a better skin moisturizer than neoagarobiose and neoagarotetraose, as the viscosity of Neoagarohexaose is higher than that of smaller oligosaccharides. Hence Microbacterium barkeri p. SELA 4 could be considered as one of the potential sources of Neoagarohexaose for industrial application.

Acknowledgment: We are grateful to the Director, IMS Engineering College Ghaziabad, for providing all the essential facilities for conducting the research work. I also feel thankful to the Director, Codon Biotech Pvt. Ltd., for necessary help regarding Sequencing.

The authors declare that no conflict of interest exists.

\section{REFERENCES}

Alonso-Echanove, J., Shah, S.S., Valenti, A.J., Dirrigl, S.N., Carson, L.A., Arduino, M.J., Jarvis, W.R. (2001). Nosocomial outbreak of Microbacterium species bacteremia among cancer patients. J Infect Dis, 184(6), 754-60. https://doi.org/10.1086/323080

PMid:11517437

Alvarado, R., Leiva, S. (2017). Agar-degrading bacteria isolated from Antarctic macroalgae. Folia Microbiol (Praha), 62(5), 409-416 https://doi.org/10.1007/s12223-017-0511-1

Chi, W.J., Chang, Y.K., Hong, S.K. (2012). Agar degradation by microorganisms and agar-degrading enzymes. Appl Microbiol Biotechnol,94(4), 917 30.https://doi.org/10.1007/s00253-012-4023-2

Duckworth, M., Turvey, J.R. (1969). An extracellular agarase from a Cytophaga species. Biochemical Journal, 113(1), 139-142.https://doi.org/10.1042/bj1130139 Feng, Z., Li, M. (2013). Purification and characterization of agarase from Rhodococcus sp. Q5, a novel agarolytic bacterium isolated from printing and dyeing wastewater. Aquaculture, 372-375, 74-79. https://doi.org/10.1016/j.aquaculture.2012.10.026

Fu, X.T., Kim, S.M. (2010). Agarase: review of major sources, categories, purification method, enzyme characteristics and applications. Mar Drugs, 8(1) 200-18.https://doi.org/10.3390/md8010200

Fu, X.T., Pan, C.H., Lin, H., Kim, S.M. (2009). Gene cloning, expression, and characterization of a beta-agarase, AgaB34, from Agarivorans albus YKW-34. J Microbiol Biotechnol, 19, 257-264. PMid:19349750

Ghazi, M., Aziz, Hala, Ali, M. (2013). Purification and Characterization of Agarase from Bacillus sp., H12. Current Research Journal of Biological Sciences, 5(1), 13-18.

Hodgkin, J., Kuwabara, P.E., Corneliussen, B. (2000). A novel bacterial pathogen, Microbacterium nematophilum, induces morphological change in the nematode C. elegans. Curr Biol, 10, 1615-1618.https://doi.org/10.1016/S09609822(00)00867-8

Hosoda, A., Sakai, M. (2006). Isolation of Asticcacaulis sp. SA7, a novel agardegrading Alphaproteo bacterium. Bioscience, Biotechnology, and Biochemistry, 70(3), 722-725. https://doi.org/10.1271/bbb.70.722 PMid:16556992

Kaku, H., Subandiyah, S., Ochiai, H. (2000). Red stripe of rice is caused by a bacterium Microbacterium sp. J. Gen Plant Pathol, 66, 149152.https://doi.org/10.1007/PL00012937

Kawaroe, M., Pratiwi, I., Sunudin, A. (2018). Isolation and characterization of marine bacteria from macroalgae Gracilaria salicornia and Gelidium latifolium on agarolytic activity for bioethanol production. In International Conference on Biomass: Technology, Application, and Sustainable Development IOP Publishing IOP Conf. Series: Earth and Environmental Science, 65 (2017) 012025 https://doi.org/10.1088/1755-1315/65/1/012025

Kim, B.C., Poo, H., Lee, K.H., Kim, M.N., Park, D.S., Oh, W., Lee, J.M., Shin, K.S. (2012). Simiduiaareninigrae sp. nov., an agarolytic bacterium isolated from sea sand. Int. J. Syst. Evol. Microbiol, 62(4), 906-11. http://doi: 10.1099/ijs.0.031153-0. PMID: 21669928.

Kim, B.J., Kim, H.J., Ha, S.H., Hwang, S.H., Byun, D.S., Lee, T.H., Kong, J.Y (1999). Purification and characterization of $\beta$ agarase from marine bacterium Bacillus cereus ASK202. Biotechnology letters, 21, 10111015.https://doi.org/10.1023/A:1005422000171
Kim, J.H., Yun, E.J., Yu, S., Kim, K.H., Kang, N.J. (2017). Different Levels of Skin Whitening Activity among 3,6-Anhydro-1-galactose, Agarooligosaccharides, and Neoagarooligosaccharides. Mar Drugs, 15(10), 321. https://doi.org/10.3390/md15100321

Kim, K.K., Park, H.Y., Park, W., Kim, I.S., Lee, S.T. (2005).Microbacterium xylanilyticum sp. nov., a xylan-degrading bacterium isolated from a biofilm. Int J Syst Evol Microbiol, 55，2075-2079.https://doi.org/10.1099/ijs.0.63706-0 PMid:16166712

Kirimura, K., Masuda, N., Iwasaki, Y., Nakagawa, H., Kobayashi, R., Usami, S. (1999). Purification and characterization of a novel $\beta$-agarase from an alkalophilic bacterium Alteromonassp. E-1. Journal of Bioscience and Bioengineering, 87, 436-441. https://doi.org/10.1016/S1389-1723(99)80091-7

Kobayashi, R., Takisada, M., Suzuki, T., Kirimura, K., Usami, S. (1997) Neoagarobiose as a novel moisturizer with whitening effect. Biosci Biotechnol Biochem, 61(1), 162-3. https://doi.org/10.1271/bbb.61.162

Laemmli, U.K. (1970). Cleavage of structural proteins during the assembly of the head of bacteriophage T4. Nature, 227, 680685.https://doi.org/10.1038/227680a0 PMid:5432063

Lakshmikanth, M., Manohar, S., Souche, Y., Lalitha, J. (2006). Extracellular $\beta$ agarase LSL-1 producing neoagarobiose from a newly isolated agar-liquefying soil bacterium, Acinetobacter sp., AG LSL-1. World J Microbiol Biotechnol, 22(10), 1087-1094.https://doi.org/10.1007/s11274-006-9147-Z

Lakshmikanth, M., Manohar, S., Lalitha, J. (2009). Purification and characterization of $\beta$-agarase from agar-liquefying soil bacterium, Acinetobacter $\begin{array}{llll}\text { sp., } & \text { AG } & \text { LSL-1. Process } & \text { Biochem, 44(9), }\end{array}$ 1003.https://doi.org/10.1016/j.procbio.2009.04.025

Leon, O., Quintana, L., Peruzzo, G., Slebe, J.C. (1992). Purification and properties of an extracellular agarase from Alteromonas sp. strain C-1. Appl Environ Microbiol, 58, 4060-4063. PMid:16348832 PMCid:PMC183228

Lewin, G.R., Carlos, C., Chevrette, M.G., Horn, H.A., McDonald, B.R., Stankey, R.J., Fox, B.G., Currie, C.R. (2016). Evolution and Ecology of Actinobacteria and their Bioenergy Applications. Annu Rev Microbiol, 70, 235-54. doi 10.1146/annurev-micro-102215-095748. https://doi.org/10.1146/annurev-micro102215-095748

Li, J., Sha, Y., Zilda, D.S., Hu, Q., He, P. (2014). Purification and Characterization of Thermostable Agarase from Bacillus sp. BI-3, a Thermophilic Bacterium Isolated from Hot Spring. J Microbiol Biotechnol, 24(1), 1925.https://doi.org/10.4014/jmb.1308.08055 PMid:24064915

Li, X., Gao, P. (1997). Isolation and partial properties of cellulose-decomposing strain of Cytophaga sp. LX-7 from soil. J Appl Microbiol,82(1), 73 - 80 https://doi.org/10.1111/j.1365-2672.1997.tb03299.x

Miller GL. Use of dinitrosalicylic acid reagent for determination of reducing sugar. Analytical Chemistry 1959; 31(3): 426-428

http://pubs.acs.org/doi/abs/10.1021/ac60147a030

Oh.,C., Nikapitiya, C., Lee,Y., Whang, I., Kang, D.H., Heo, S.J., Choi, Y.U., Lee, J. (2010). Molecular cloning, characterization and enzymatic properties of a novel Beta-agarase from a marine isolate Pseudoalteromonas SP. AG52.

Brazilian Journal of Microbiology, 41(4), 876-889.

http://dx.doi.org/10.1590/S1517-83822010000400006

Ohta, Y., Hatada, Y., Nogi, Y., Miyazaki, M., Li, Z., Akita, M., Hidaka, Y., Goda, S., Ito, S., Horikoshi, K. (2004). Enzymatic properties and nucleotide and amino acid sequences of a thermostable beta-agarase from a novel species of deep-sea Microbulbifer. Appl Microbiol Biotechnol, 64(4), 505-14 https://doi.org/10.1007/s00253-004-1573-y PMid:15088129

Qian, F., An, L., Wang, M., Li, C., Li, X. (2007). Isolation and characterization of a xanthan-degrading Microbacterium sp. strain XT11 from garden soil. J Appl Microbiol, 102(5), 1362-71. https://doi.org/10.1111/i.1365-2672.2006.03215.x PMid: 17448171

Rajagopal, G., Kannan, S. (2016). Systematic characterization of potential cellulolytic marine actinobacteria Actinoalloteichus sp. MHA15. Biotechnol Rep, 13, 30-36. https://doi.org/10.1016/j.btre.2016.12.003

Sakai, M., Deguchi, D., Hosoda, A., Kawauchi, T., Ikenaga, M (2015).Ammoniibacillus agariperforans gen. nov., sp. nov., athermophilic, agardegrading bacterium isolated from compost. Int J Syst Evol Microbiol, 65(2), 570-577.https://doi.org/10.1099/ijs.0.067843-0PMid:25404482

Sartori, M., Nesci, A., Etcheverry, M. (2012). Production of Fusarium verticillioides biocontrol agents, Bacillus amyloliquefaciens and Microbacterium oleovorans, using different growth media: evaluation of biomass and viability after freeze-drying. Food Addit ContamPart A Chem Anal Control Expo Risk Assess, 29, 287-292. https://doi.org/10.1080/19440049.2011.563369 PMid:21547798

Solvanikova, I.P., Golovleva, L.A. (2015). Physiological and biochemical properties of actinobacteria as the basis of their high biodegradative activity $\begin{array}{llrr}\text { (review). Prikl Biokhim } \quad \text { Mikrobiol, } & \text { 51(2), }\end{array}$ https://doi.org/10.7868/S0555109915020208PMid:26027348PMid:26027348 Song, T., Cao, Y., Xu, H., Zhang, W., Fei, B., Qiao, D., Cao, Y. (2014) Purification and characterization of a novel $\beta$-agarase of Paenibacillus sp. SSG-1 isolated from soil. $J$ Biosci Bioeng,118(2), 125- 
129.https://doi.org/10.1016/i.jbiosc.2014.02.008

PMid:24631192

Song T, Zhang W, Wei C, Jian, T., Xu, H., Cao, Y., Qiao, D. (2015). Isolation and characterization of agar-degrading endophytic bacteria from plants. Curr Microbiol, $\quad 70(2), \quad$ 275-281.https://doi.org/10.1007/s00284-014-07136PMid:25331792

Sugano, Y., Terada, I., Arita, M., Noma, M. (1993). Purification and characterization of a new agarase from a marine bacterium, Vibrio sp. Strain JacT0107. Appl Environ Microbiol, 59, 1549-1554. PMid:8517750 PMCid:PMC182117

Suzuki, H., Sawai, Y., Suzuki, T., Kawai, K. (2002). Purification and characterization of an extracellular alpha-neoagarooligosaccharide hydrolase from Bacillus sp. MK03. J Biosci Bioeng, 93(5), 456-63. https://doi.org/10.1016/S1389-1723(02)80092-5

Suzuki, H., Sawai, Y., Suzuki, T., Kawai, K. (2003). Purification and characterization of an extracellular $\beta$-agarase from Bacillus sp. MK03. Journal of Bioscience and Bioengineering, 95(4), 328-334. https://doi.org/10.1016/S13891723(03)80063-4

Temuujin, U., Chi, W.J., Chang, Y.K., Hong, S.K. (2012). Identification and biochemical characterization of Sco3487 from Streptomyces coelicolor A3(2), an exo- and endo-type $\beta$-agarase-producing neoagarobiose. J Bacteriol, 194(1), 1429.https://doi.org/10.1128/JB.05978-11 PMid:22020647 PMCid:PMC3256618

Vera, J., Alvarez, R., Murano, E., Slebe, J.C., Leon, O. (1998). Identification of a Marine Agarolytic Pseudoalteromonas Isolate and Characterization of Its Extracellular Agarase. Appl Environ Microbiol, 64(11), 4378-4383. PMid:9797294 PMCid:PMC106656

Wang, J., Jiang, X., Mou, H. (2004). Anti-oxidation of agar oligosaccharides produced by agarase from a marine bacterium. J Appl Phycol, 16(5), 333340.https://doi.org/10.1023/b:japh.0000047944.40463.e6

Yoshizawa. Y., Ametani, A., Tsunehiro, J., Nomura, K., Itoh, M., Fukui, F., Kaminogawa, S. (1995). Macrophage stimulation activity of the polysaccharide fraction from a marine alga (Porphyra yezoensis): structure-function relationships and improved solubility. Biosci Biotechnol Biochem, 59(10), 1933-7. https://doi.org/10.1271/bbb.59.1933PMid:8534986 